\title{
Synthesis of a FLAP Inhibitor
}<smiles>C[C@H](OC(=O)NP)c1ccc(Br)cc1</smiles>

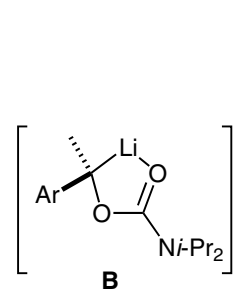<smiles>CC1CC(C)C(C)(C)O1</smiles>

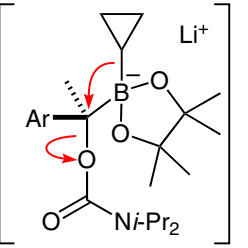

D $99 \%$ assay yield 1,2-metalate rearrangement inversion

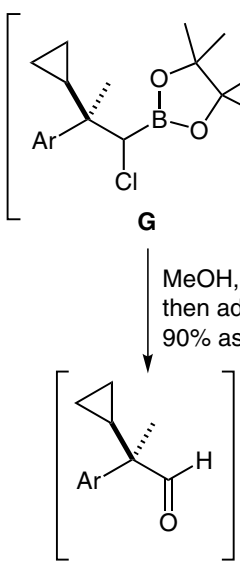<smiles>[V]C1CC1</smiles>

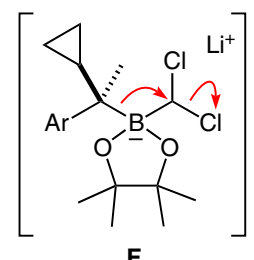
$\mathrm{LiCHCl}_{2}$ (2.0 equiv) THF-dioxane
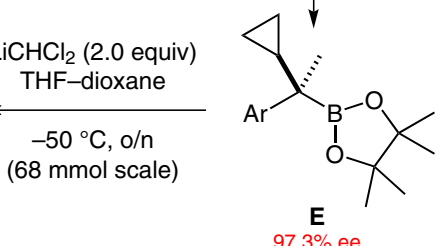
$97.3 \% \mathrm{ee}$

\section{Gategory}

Synthesis of Natural

Products and

Potential Drugs

\section{Key words}

FLAP inhibitors

1,2-metalate rearrangement

quaternary centers

stereoselective metalation
Significance: The target molecule inhibits the 5lipoxygenase-activating protein (FLAP) that is implicated in the biosynthesis of leukotriene. It is of interest for the treatment of atherosclerosis. The noteworthy feature of this synthesis is the construction of the quaternary center in the aldehyde H using two tandem 1,2-metalate rearrangements.
Comment: The enantiopure carbamate A was derived from 4-bromoacetophenone using a Noyori asymmetric transfer hydrogenation. Metalation of carbamate $\mathbf{A}$ with LDA under noncryogenic conditions in the presence of boronate $\mathbf{C}$ gave adduct $\mathbf{D}$ with retention of configuration. For an alternative synthesis of $\mathbf{H}$, see: X. Zeng et al. Angew. Chem. Int. Ed. 2014, 53, 12153.

SYNFACTS Contributors: Philip Kocienski 